\title{
Impact of New Laboratory Studies of N205 Hydrolysis on Global Model Budgets of Tropospheric Nitrogen Oxides, Ozone, and $\mathrm{OH}$
}

\section{Citation}

Evans, M.J, and Daniel J. Jacob. 2005. Impact of new laboratory studies of N205 hydrolysis on global model budgets of tropospheric nitrogen oxides, ozone, and $\mathrm{OH}$. Geophysical Research Letters 32(L09813): 1-4.

\section{Published Version}

doi:10.1029/2005GL022469

\section{Permanent link}

http://nrs.harvard.edu/urn-3:HUL.InstRepos:3988779

\section{Terms of Use}

This article was downloaded from Harvard University's DASH repository, and is made available under the terms and conditions applicable to Other Posted Material, as set forth at http:// nrs.harvard.edu/urn-3:HUL.InstRepos:dash.current.terms-of-use\#LAA

\section{Share Your Story}

The Harvard community has made this article openly available.

Please share how this access benefits you. Submit a story.

\section{Accessibility}




\title{
Impact of new laboratory studies of $\mathrm{N}_{2} \mathrm{O}_{5}$ hydrolysis on global model budgets of tropospheric nitrogen oxides, ozone, and $\mathrm{OH}$
}

\author{
M. J. Evans ${ }^{1}$ and D. J. Jacob \\ Division of Engineering and Applied Science, Harvard University, Cambridge, Massachusetts, USA
}

Received 18 January 2005; revised 7 March 2005; accepted 8 April 2005; published 13 May 2005.

[1] We investigate the impact of new laboratory studies of $\mathrm{N}_{2} \mathrm{O}_{5}$ hydrolysis in aerosols on global model simulations of tropospheric chemistry. We use data from these new studies to parameterize the reaction probability $\left(\gamma_{\mathrm{N} 2 \mathrm{O} 5}\right)$ in the GEOS-CHEM global model as a function of local aerosol composition, temperature, and relative humidity. We find a much lower global mean $\gamma_{\mathrm{N} 2 \mathrm{O} 5}(0.02)$ than commonly assumed in models (0.1). Relative to a model simulation assuming a uniform $\gamma_{\mathrm{N} 2 \mathrm{O} 5}=0.1$, we find increases in massaveraged tropospheric $\mathrm{NO}_{\mathrm{x}}, \mathrm{O}_{3}$, and $\mathrm{OH}$ concentrations of $7 \%, 4 \%$, and $8 \%$ respectively. The increases in $\mathrm{NO}_{\mathrm{x}}$ and $\mathrm{O}_{3}$ concentrations bring the GEOS-CHEM simulation in better agreement with climatological observations. Citation: Evans, M. J., and D. J. Jacob (2005), Impact of new laboratory studies of $\mathrm{N}_{2} \mathrm{O}_{5}$ hydrolysis on global model budgets of tropospheric nitrogen oxides, ozone, and $\mathrm{OH}$, Geophys. Res. Lett., 32, L09813, doi:10.1029/2005GL022469.

\section{Introduction}

[2] Reactive oxides of nitrogen $\left(\mathrm{NO}_{\mathrm{x}} \equiv \mathrm{NO}+\mathrm{NO}_{2}\right)$ play a defining role in the chemistry of the troposphere. They react catalytically to produce ozone $\left(\mathrm{O}_{3}\right)$ and $\mathrm{OH}$, the main tropospheric oxidants. The dominant global source of $\mathrm{NO}_{\mathrm{x}}$ is the burning of fossil fuel $\left(20-33 \mathrm{Tg} \mathrm{N} \mathrm{yr}^{-1}\right)$ with minor contributions from biomass and biofuel burning (collectively 3-13 $\mathrm{Tg} \mathrm{N} \mathrm{yr}^{-1}$ ), soils (4-7 $\mathrm{Tg} \mathrm{N} \mathrm{yr}^{-1}$ ), and lightning (3$13 \mathrm{Tg} \mathrm{N} \mathrm{yr}^{-1}$ ) [Intergovernmental Panel on Climate Change (IPCC), 2001]. $\mathrm{NO}_{\mathrm{x}}$ is permanently removed from the atmosphere by conversion to nitric acid followed by deposition. During the day, this conversion occurs through the reaction of $\mathrm{NO}_{2}$ with $\mathrm{OH}$, and during the night by hydrolysis of $\mathrm{N}_{2} \mathrm{O}_{5}$ in aerosols. These mechanisms are globally comparable as sinks of $\mathrm{NO}_{\mathrm{x}}$ [Dentener and Crutzen, 1993]. Previous evaluations of the literature based upon work undertaken for stratospheric conditions [Jacob, 2000] gave a best estimate of 0.1 for the reaction probability of $\mathrm{N}_{2} \mathrm{O}_{5}$ $\left(\gamma_{\mathrm{N} 2 \mathrm{O} 5}\right)$, i.e. the probability that a $\mathrm{N}_{2} \mathrm{O}_{5}$ molecule impacting an aerosol surface undergoes reaction. This value has been the standard used in many tropospheric chemistry models [Dentener and Crutzen, 1993; Wang et al., 1998; Bey et al., 2001; Tie et al., 2001; Stroud et al., 2003]. A study by Tie et al. [2003] found that $\gamma_{\mathrm{N} 2 \mathrm{O} 5}=0.04$ or less gave a better simulation of $\mathrm{NO}_{\mathrm{x}}$ concentrations observed during the TOPSE aircraft campaign over the North American Arctic. Photochemical model analyses of observed $\mathrm{NO}_{\mathrm{x}} / \mathrm{HNO}_{3}$

\footnotetext{
${ }^{1}$ Now at Institute for Atmospheric Science, School of Earth and Environment, University of Leeds, Leeds, UK.
}

Copyright 2005 by the American Geophysical Union. 0094-8276/05/2005GL022469\$05.00 ratios in the upper troposphere have also suggested that $\gamma_{\mathrm{N} 2 \mathrm{O} 5}$ is much less than 0.1 [McKeen et al., 1997; Schultz et al., 2000]. Recent laboratory studies of $\mathrm{N}_{2} \mathrm{O}_{5}$ hydrolysis [Kane et al., 2001; Hallquist et al., 2003; Thornton et al., 2003] provide sufficient information to improve the representation of $\gamma_{\mathrm{N} 2 \mathrm{O} 5}$ in global models as a function of local aerosol composition, relative humidity (R.H.), and temperature. We examine here the implications for model simulations of the global tropospheric budgets of $\mathrm{NO}_{\mathrm{x}}, \mathrm{O}_{3}$, and $\mathrm{OH}$.

\section{Model Calculation of $\mathbf{N}_{2} \mathrm{O}_{5}$ Reaction Probability}

[3] Our analysis uses the GEOS-CHEM chemical transport model (CTM) which has been used previously for a number of studies focused on tropospheric $\mathrm{O}_{3}-\mathrm{OH}-\mathrm{NO}_{\mathrm{x}}$ budgets [e.g., Bey et al., 2001; Martin et al., 2003a; Hudman et al., 2004]. We use GEOS-CHEM version 5-07-08 (http:// www-as.harvard.edu/chemistry/trop/geos). This version of the model considers five different aerosol components: dust, sulfate, organic carbon, black carbon, and sea salt. The sulfate aerosol mass concentration is calculated within the model [Park et al., 2004] and the mass concentration of the other components are specified as 3-D monthly mean values from the GOCART model [Chin et al., 2000a, 2000b; Ginoux et al., 2001; Martin et al., 2003b]. Size distributions for all aerosol components are specified as described by [Martin et al., 2003b].

[4] Past applications of GEOS-CHEM have assumed $\gamma_{\mathrm{N} 2 \mathrm{O} 5}=0.1$ for all aerosol types and conditions. In the present study we specify $\gamma_{\mathrm{N} 2 \mathrm{O} 5}$ for different aerosol components and conditions on the basis of recent laboratory studies [Kane et al., 2001; Hallquist et al., 2003; Thornton et al., 2003]. Kane et al. [2001] investigated the effect of R.H. over the range $8-92 \%$ on $\gamma_{\mathrm{N} 2 \mathrm{O} 5}$ for ammonium sulfate, ammonium bisulfate, and sulfuric acid aerosols. We assume here that atmospheric sulfate aerosol is mainly present as ammonium sulfate, a reasonable assumption at least over continental regions [Martin et al., 2004] where $\mathrm{N}_{2} \mathrm{O}_{5}$ hydrolysis is globally most important. Kane et al. [2001] found that $\gamma_{\mathrm{N} 2 \mathrm{O} 5}$ increases smoothly from $9.4 \times$ $10^{-4}$ at $8 \%$ R.H. to 0.042 at $92 \%$. Hallquist et al. [2003] investigated the effect of temperature and found that $\gamma_{\mathrm{N} 2 \mathrm{O} 5}$ for ammonium sulfate had a roughly constant value of 0.03 up to $280 \mathrm{~K}$ with a rapid decrease to 0.003 at $308 \mathrm{~K}$. For our study we have adopted the R.H. parameterization of Kane et al. [2001] and the temperature dependence of Hallquist et al. [2003]. Thornton et al. [2003] investigated $\mathrm{N}_{2} \mathrm{O}_{5}$ uptake by organic aerosols using malonic acid particles. They found $\gamma_{\mathrm{N} 2 \mathrm{O} 5}$ on solid aerosol (R.H. between 0 and 50\%) to be 0.001 . For aqueous aerosols, $\gamma_{\mathrm{N} 2 \mathrm{O} 5}$ increased from 
Table 1. GEOS-CHEM Representation of the Reaction Probability $\gamma_{\mathrm{N} 2 \mathrm{O} 5}$ for $\mathrm{N}_{2} \mathrm{O}_{5}$ Hydrolysis on Aerosol Surfaces

\begin{tabular}{|c|c|c|}
\hline Aerosol Type & Reaction Probability $^{\mathrm{a}}$ & Reference \\
\hline Sulfate $^{b}$ & $\begin{aligned} \gamma= & \alpha \times 10^{\beta} \\
\alpha= & 2.79 \times 10^{-4}+1.3 \\
& \times 10^{-4} \times \mathrm{RH}-3.43 \\
& \times 10^{-6} \times \mathrm{RH}^{2}+7.52 \\
& \times 10^{-8} \times \mathrm{RH}^{3} \\
\beta= & 4 \times 10^{-2} \\
& \times(\mathrm{T}-294)(\mathrm{T} \geq 282 \mathrm{~K}) \\
\beta= & -0.48(\mathrm{~T}<282 \mathrm{~K})\end{aligned}$ & Hallquist et al. $[2003]^{\mathrm{c}}$ \\
\hline Organic carbon & $\begin{aligned} \gamma= & \mathrm{RH} \times 5.2 \\
& \times 10^{-4}(\mathrm{RH}<57 \%) \\
\gamma= & 0.03(\mathrm{RH} \geq 57 \%)\end{aligned}$ & Thornton et al. $[2003]^{\mathrm{d}}$ \\
\hline Black carbon & $\gamma=0.005$ & Sander et al. [2003] \\
\hline Sea salt & $\begin{array}{l}\gamma=0.005(\mathrm{RH}<62 \%) \\
\gamma=0.03(\mathrm{RH} \geq 62 \%)\end{array}$ & Sander et al. $[2003]^{\mathrm{e}}$ \\
\hline Dust & $\gamma=0.01$ & Bauer et al. $[2004]^{\mathrm{f}}$ \\
\hline
\end{tabular}

${ }^{\mathrm{a}} \mathrm{T}$ is temperature (K), RH is relative humidity (\%).

${ }^{\mathrm{b}} \mathrm{We}$ assume a separable relationship between R.H. and temperature effects on $\gamma_{\mathrm{N} 2 \mathrm{O} 5}$, using the work by Kane et al. [2001] for the R.H. effect and Hallquist et al. [2003] for the temperature effect.

${ }^{c}$ Logarithmic fit of data presented in Figure 11 of Hallquist et al. [2003].

${ }^{\mathrm{d}}$ Linear fit of data presented in Figure 6 of Thornton et al. [2003].

${ }^{\mathrm{e}}$ We use the work of Sander et al. [2003] for the reaction probability on dry and aqueous sea-salt aerosol, and assume that the aerosol is dry for $\mathrm{RH}<62 \%$, corresponding to the midpoint between deliquescence and efflorescence R.H. [Martin, 2000].

${ }^{\mathrm{f}}$ No value available from published literature. Bauer et al. [2004] quote a range from 0.003 to 0.02 from unpublished measurements by J. Crowley as part of the MINATROC EU Commission project EVK2-CT-1999-00003.

0.01 to 0.03 as R.H. increased from 20 to $50 \%$, (between 20 and $50 \%$ R.H. a metastable state exists) with values remaining constant at around 0.03 for R.H. above this. It appears that for much of the atmosphere organic aerosols are aqueous [Bradan and Abbatt, 2004; Marcolli et al., 2004] so we assume here the aqueous range of values.

[5] Table 1 describes the updated parameterization of $\gamma_{\mathrm{N} 2 \mathrm{O} 5}$ in GEOS-CHEM based on these and other data. We present here results from two one-year GEOS-CHEM simulations for 2001. The first simulation uses a uniform $\gamma_{\mathrm{N} 2 \mathrm{O} 5}=0.1$ and the second uses the parameterization described in Table 1. Both simulations were initialized with a 12-month spin-up. The horizontal resolution used is $4^{\circ} \times 5^{\circ}$ and there are 30 vertical layers from the surface

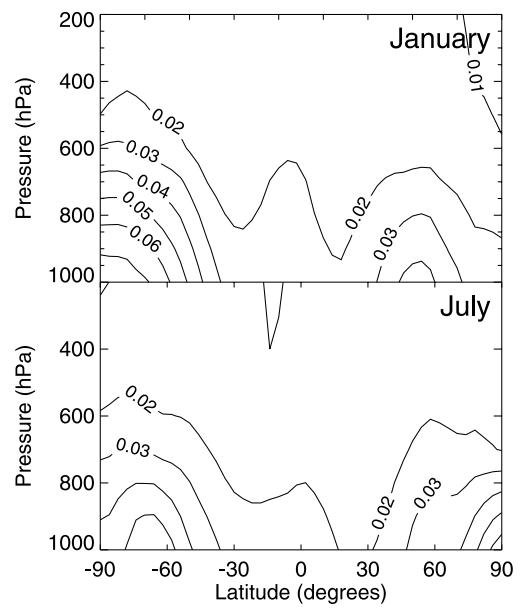

Figure 1. Zonal mean $\mathrm{N}_{2} \mathrm{O}_{5}$ reaction probabilities $\left(\gamma_{\mathrm{N} 2 \mathrm{O} 5}\right)$ for January and July 2001, calculated in the GEOS-CHEM global model using the expressions of Table 1. to $50 \mathrm{hPa}$. Further details of the tropospheric chemistry simulations in GEOS-CHEM are presented, for example, by Bey et al. [2001] and Martin et al. [2003a].

[6] Figure 1 shows the zonal mean $\gamma_{\mathrm{N} 2 \mathrm{O} 5}$ values for January and July as computed in GEOS-CHEM from the data in Table 1. $\gamma_{\mathrm{N} 2 \mathrm{O} 5}$ for each grid-box is calculated as the mean $\gamma_{\mathrm{N} 2 \mathrm{O} 5}$ over all aerosol components weighted by the relative contribution of each component to the total aerosol surface area of that grid-box. Much of the spatial and seasonal variability in Figure 1 reflects the temperature and R.H. dependences of $\gamma_{\mathrm{N} 2 \mathrm{O} 5}$ on sulfate aerosol. Values are highest in surface air at the summertime poles and at northern mid-latitudes in winter because of cold temperatures, high R.H., and a large contribution of sulfate to the total aerosol surface area. The general decrease of $\gamma_{\mathrm{N} 2 \mathrm{O} 5}$ with altitude is due to the decrease in R.H., leading to minima in the very low R.H. downward branches of the Hadley circulation. The global mean $\gamma_{\mathrm{N} 2 \mathrm{O} 5}$ is 0.02 . During the spring months in the Arctic, $\gamma_{\mathrm{N} 2 \mathrm{O} 5}$ ranges from 0.01 to 0.04 which is within the range found by Tie et al. [2003] to match the TOPSE $\mathrm{NO}_{\mathrm{x}}$ observations. The low values in the upper troposphere $(\sim 0.01)$ are consistent with $\mathrm{HNO}_{3} / \mathrm{NO}_{\mathrm{x}}$ concentration ratios measured from aircraft [McKeen et al., 1997; Schultz et al., 2000].

\section{Impact on Global Model Budgets}

[7] Figure 2 shows the calculated zonal mean fractional change in the concentrations of $\mathrm{NO}_{\mathrm{x}}, \mathrm{O}_{3}$ and $\mathrm{OH}$ for DecFeb and Jun-Aug with the new parameterization for $\gamma_{\mathrm{N} 2 \mathrm{O} 5}$,

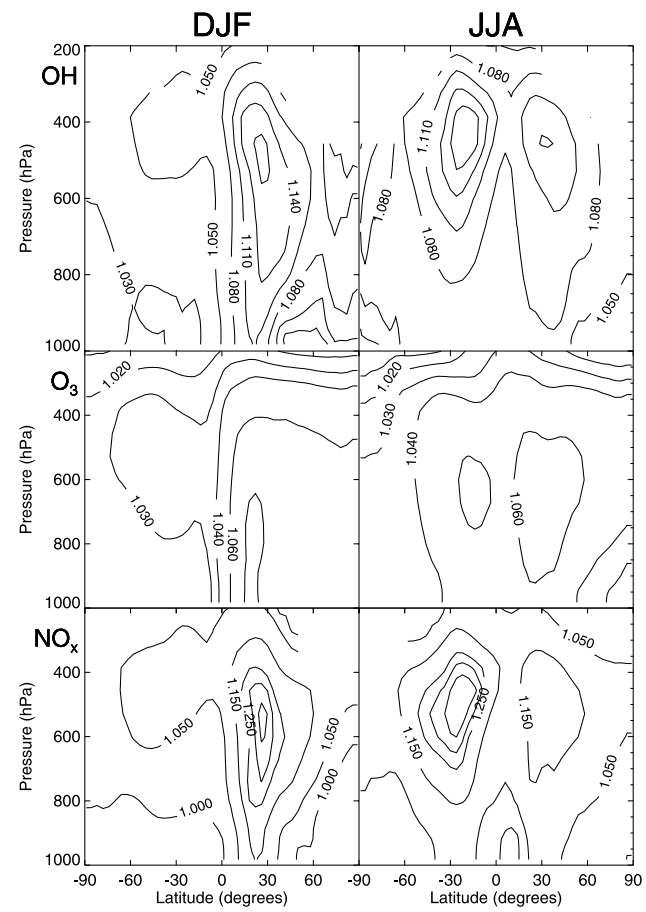

Figure 2. Calculated zonal mean concentration ratios of $\mathrm{OH}$, ozone, and $\mathrm{NO}_{\mathrm{x}}$ for GEOS-CHEM model simulations with $\gamma_{\mathrm{N} 2 \mathrm{O} 5}$ values calculated from Table 1 versus a uniform value of 0.1 . Results are seasonal averages for winter (DJF) and summer (JJA). Values greater than 1 indicate higher concentrations with the $\gamma_{\mathrm{N} 2 \mathrm{O} 5}$ values calculated from Table 1 than with a uniform $\gamma_{\mathrm{N} 2 \mathrm{O} 5}$ of 0.1 . 
as compared to the simulation with $\gamma_{\mathrm{N} 2 \mathrm{O} 5}=0.1$. The tropospheric $\mathrm{NO}_{\mathrm{x}}$ burden increases from $9.6 \mathrm{Gg} \mathrm{N}$ to $10.2 \mathrm{Gg} \mathrm{N}(7 \%)$. The largest increases $(\sim 50 \%)$ are found in winter in the downward branch of the Hadley circulation, consistent with the reduction in $\gamma_{\mathrm{N} 2 \mathrm{O} 5}$ associated with these dry warm conditions (Figure 1). On a global mass-weighted basis, $\mathrm{N}_{2} \mathrm{O}_{5}$ concentrations are $250 \%$ higher and $\mathrm{NO}_{3}$ concentrations are $30 \%$ higher. Comparison of model results with a compilation of aircraft observations of $\mathrm{NO}_{\mathrm{x}}$ concentrations mapped onto a monthly $4^{\circ} \times 5^{\circ}$ grid [Emmons et al., 2000] shows a reduction in the massweighted model bias from $-14.0 \mathrm{pptv}$ to $-7.9 \mathrm{pptv}$ with the new $\gamma_{\mathrm{N} 2 \mathrm{O} 5}$ parameterization. The mean ratio of simulated to observed $\mathrm{NO}_{\mathrm{x}}$ concentrations for that compilation increases from 0.77 to 0.86 . The largest change is in the middle troposphere $(3-10 \mathrm{~km})$ where the mean ratio increases from 0.79 to 0.91 .

[8] Simulated $\mathrm{O}_{3}$ concentrations increase with the new $\mathrm{N}_{2} \mathrm{O}_{5}$ hydrolysis parameterization, responding to the increased $\mathrm{NO}_{\mathrm{x}}$ concentrations. The total burden of tropospheric $\mathrm{O}_{3}$ increases by $4 \%$ from $249 \mathrm{Gg}$ to $260 \mathrm{Gg}$. Comparison with the climatological compilation of tropospheric ozonesonde data by [Logan, 1999] shows a reduction in the mass-weighted model bias from $-2.9 \mathrm{ppbv}$ to $-1.4 \mathrm{ppbv}$. The mass-weighted model to measured concentration ratio improves from 0.94 to 0.99 . The global $\mathrm{O}_{\mathrm{x}}$ (odd oxygen) chemical production increases within the troposphere by $7 \%$ from $3900 \mathrm{Tg} \mathrm{O}_{3} \mathrm{yr}^{-1}$ to $4180 \mathrm{Tg}$ $\mathrm{O}_{3} \mathrm{yr}^{-1}$. An intercomparison between 10 global tropospheric chemistry models [IPCC, 2001] found a global mean $\mathrm{O}_{\mathrm{x}}$ production rate of $3365 \pm 745 \mathrm{Tg} \mathrm{O}_{3} \mathrm{yr}^{-1}$ across all the models. GEOS-CHEM is at the high end of this range, but we have argued that this could reflect biases in other models [Bey et al., 2001].

[9] The combined effect of increasing the $\mathrm{NO}_{\mathrm{x}}$ and $\mathrm{O}_{3}$ concentrations is an increase in the concentration of $\mathrm{OH}$. The mass-weighted, global annual mean tropospheric $\mathrm{OH}$ concentration increases from $0.99 \times 10^{6} \mathrm{~cm}^{-3}$ to $1.08 \times 10^{6} \mathrm{~cm}^{-3}$ (an $8 \%$ increase $)$. Both values are consistent with the current constraints on global mean $\mathrm{OH}$ concentrations based on methyl-chloroform observations: $1.07\left({ }^{+0.09}-0.17\right) \times 10^{6} \mathrm{~cm}^{-3}$ [Krol et al., 1998], $1.16 \pm 0.17 \times 10^{6} \mathrm{~cm}^{-3}$ [Spivakovsky et al., 2000], and $0.94 \pm 0.13 \times 10^{6} \mathrm{~cm}^{-3}$ [Prinn et al., 2001].

[10] The new parameterization for $\gamma_{\mathrm{N} 2 \mathrm{O} 5}$ described in Table 1 thus has significant impact on simulations of tropospheric composition and points to the need for further work to characterize $\mathrm{N}_{2} \mathrm{O}_{5}$ uptake by aerosols. There are to our knowledge no laboratory data for $\gamma_{\mathrm{N} 2 \mathrm{O} 5}$ on dust aerosols, which make a large contribution to total aerosol surface area. Uncertainties in organic aerosol phase, and in the mixing states between different aerosol types, are also major issues.

[11] Acknowledgments. The work at Harvard was supported by the NASA Atmospheric Chemistry Modeling and Analysis Program. MJE acknowledges the support of a NERC Fellowship.

\section{References}

Bauer, S. E., Y. Balkanski, M. Schulz, D. A. Hauglustaine, and F. Dentener (2004), Global modeling of heterogenous chemistry on mineral aerosol surfaces: Influence on tropospheric ozone chemistry and comparison to observations, J. Geophys. Res., 109, D02304, doi:10.1029/ 2003JD003868.
Bey, I., D. J. Jacob, R. M. Yantosca, J. A. Logan, B. D. Field, A. M. Fiore, Q. Li, H. Y. Liu, L. J. Mickley, and M. G. Schultz (2001), Global modeling of tropospheric chemistry with assimilated meteorology: Model description and evaluation, J. Geophys. Res., 106, 23,073-23,096.

Bradan, C. F., and J. P. D. Abbatt (2004), A study of the phase transition behavior of internally mixed ammonium sulfate-malonic acid aerosols, Atmos. Chem. Phys., 4, 1451-1459.

Chin, M., P. Ginoux, S. Kinne, O. Torres, B. Holben, B. N. Duncan, R. V. Martin, J. A. Logan, A. Higurashi, and T. Nakajima (2000a), Atmospheric sulfur cycle simulated in the global model GOCART: Comparison with field observations and regional budgets, J. Geophys. Res., 105, 24,689-24,712.

Chin, M., R. B. Rood, S.-J. Lin, J. F. Muller, and A. M. Thompon (2000b), Atmospheric sulfur cycle simulated in the global model GOCART: Model description and global properties, J. Geophys. Res., 105, 24,671-24,687.

Dentener, F. J., and P. J. Crutzen (1993), Reaction of $\mathrm{N}_{2} \mathrm{O}_{5}$ on tropospheric aerosols: Impact on the global distribution of $\mathrm{NO}_{\mathrm{x}}, \mathrm{O}_{3}$, and $\mathrm{OH}, \mathrm{J}$. Geophys. Res., 98, 7149-7163.

Emmons, L. K., D. A. Hauglustaine, J.-F. Muller, M. A. Carroll, G. P. Brasseur, D. Brunner, J. Staehelin, V. Thouret, and A. Marenco (2000), Data composites of airborne observations of tropospheric ozone and its precursors, J. Geophys. Res., 105, 20,497-20,538.

Ginoux, P. M., M. Chin, I. Tegen, J. M. Prospero, B. Holben, O. Dubovik, and S. Lin (2001), Sources and distributions of dust aerosols simulated with the GOCART model, J. Geophys. Res., 106, 22,055-22,074.

Hallquist, M., D. J. Stewart, S. K. Stephenson, and R. A. Cox (2003), Hydrolysis of $\mathrm{N}_{2} \mathrm{O}_{5}$ on sub-micron sulfate aerosol, Phys. Chem. Chem. Phys, 5(16), 3453-3463.

Hudman, R. C., et al. (2004), Ozone production in transpacific Asian pollution plumes and implications for ozone air quality in California, J. Geophys. Res., 109, D23S10, doi:10.1029/2004JD004974.

Intergovernmental Panel on Climate Change (IPCC) (2001), Climate Change 2001: The Scientific Basis, edited by J. T. Houghton et al., 892 pp., Cambridge Univ. Press, New York.

Jacob, D. J. (2000), Heterogenous chemistry and tropospheric ozone, Atmos. Environ., 34, 2131-2159.

Kane, S. M., F. Caloz, and M. T. Leu (2001), Heterogenous uptake of gaseous $\mathrm{N}_{2} \mathrm{O}_{5}$ by $\left(\mathrm{NH}_{4}\right)_{2} \mathrm{SO}_{4}, \mathrm{NH}_{4} \mathrm{HSO}_{4}$ and $\mathrm{H}_{2} \mathrm{SO}_{4}$ aerosol, J. Phys. Chem, 105(26), 6465-6570.

Krol, M., P. J. van Leeuwen, and J. Lelieveld (1998), Global OH trends inferred from methyl-chloroform measurements, J. Geophys. Res., 103, $10,697-10,711$.

Logan, J. A. (1999), An analysis of ozonesonde data for the troposphere: Recommendations for testing 3-D models and development of a gridded climatology for tropospheric ozone, J. Geophys. Res., 104, 16,11516,149 .

Marcolli, C., B. P. Luo, and T. Peter (2004), Mixing of the organic aerosol fractions: Liquids as the thermodynamically stable phases, J. Phys. Chem. A, 108(12), 2216-2224.

Martin, R. V., D. J. Jacob, K. V. Chance, T. P. Kurosu, P. I. Palmer, and M. J. Evans (2003a), Global inventory of nitrogen oxide emissions constrained by space-based observations of $\mathrm{NO}_{2}$ columns, J. Geophys. Res., 108(D17), 4537, doi:10.1029/2003JD003453.

Martin, R. V., D. J. Jacob, R. M. Yantosca, M. Chin, and P. Ginoux (2003b), Global and regional decreases in tropospheric oxidants from photochemical effects of aerosols, J. Geophys. Res., 108(D3), 4097, doi:10.1029/2002JD002622.

Martin, S. (2000), Phase transitions of aqueous atmospheric particles, Chem. Rev., 100, 3403-3453.

Martin, S. T., H.-M. Hung, R. J. Park, D. J. Jacob, R. J. D. Spurr, K. V. Chance, and M. Chin (2004), Effects of the physical state of tropospheric ammonium-sulfate-nitrate particles on global aerosol direct radiative forcing, Atmos. Chem. Phys., 4, 183-214.

McKeen, S. A., J. B. Gierczak, J. B. Burkholder, P. O. Wennberg, T. F. Hanisco, E. R. Keim, R.-S. Gao, A. R. Ravishankara, and D. W. Fahey (1997), The photochemistry of acetone in the upper troposphere: A source of odd-hydrogen radicals, Geophys. Res. Lett., 24, 3177-3180.

Park, R. J., D. J. Jacob, B. D. Field, R. M. Yantosca, and M. Chin (2004), Natural and transboundary pollution influences on sulfate-nitrateammonium aerosols in the United States: Implications for policy, J. Geophys. Res., 109, D15204, doi:10.1029/2003JD004473.

Prinn, R. G., et al. (2001), Evidence for substantial variations in atmospheric hydroxyl radicals in the past two decades, Science, 292, 1882-1888.

Sander, S. P., et al. (2003), Chemical kinetics and photochemical data for use in atmospheric studies, evaluation number 14, JPL Publ., 02-25, 334 pp. Schultz, M. G., D. J. Jacob, J. D. Bradshaw, S. T. Sandholm, J. E. Dibb, R. W. Talbot, and H. B. Singh (2000), Chemical $\mathrm{NO}_{x}$ budget in the upper troposphere over the tropical South Pacific, J. Geophys. Res., 105, 66696679. 
Spivakovsky, C. M., et al. (2000), Three-dimensional climatological distribution of tropospheric $\mathrm{OH}$ : Update and evaluation, J. Geophys. Res., $105,8931-8980$

Stroud, C., et al. (2003), Photochemistry in the arctic free troposphere: $\mathrm{NO}_{x}$ budget and the role of odd nitrogen reservoir recycling, Atmos. Environ., $37(24), 3351-3364$.

Thornton, J. A., C. F. Braban, and J. P. D. Abbatt (2003), $\mathrm{N}_{2} \mathrm{O}_{5}$ hydrolysis on sub-micron organic aerosol: The effect of relative humidity, particle phase and particle size, Phys. Chem. Chem. Phys., 5(20), 4593-4603.

Tie, X., G. Brasseur, L. Emmons, L. Horowitz, and D. Kinnison (2001), Effects of aerosols on tropospheric oxidants: A global model study, J. Geophys. Res., 106, 22,931-22,964.
Tie, X., et al. (2003), Effect of sulfate aerosol on tropospheric $\mathrm{NO}_{x}$ and ozone budgets: Model simulations and TOPSE evidence, J. Geophys. Res., 108(D4), 8364, doi:10.1029/2001JD001508.

Wang, Y., D. J. Jacob, and J. A. Logan (1998), Global simulation of troposphere $\mathrm{O}_{3}-\mathrm{NO}_{x}$-hydrocarbon chemistry: 1. Model formulation, J. Geophys. Res., 103, 10,713-10,725.

M. J. Evans, Institute for Atmospheric Science, School of Earth and Environment, University of Leeds, Leeds LS2 9JT, UK. (mat@env.leeds. ac.uk)

D. J. Jacob, Division of Engineering and Applied Science, Harvard University, Oxford Street, Cambridge, MA 02138, USA. 